\title{
PENINGKATAN BERPIKIR KRITIS MENGGUNAKAN STRATEGI PEMBELAJARAN VIDEO CRITIC BERBASIS ATONG
}

\author{
Habib Nurrokhman ${ }^{1}$, Aji Heru Muslim ${ }^{2}$, Yudha Febrianta ${ }^{3}$ \\ PGSD, Universitas Muhammadiyah Purwokerto ${ }^{123}$ \\ Email: nurrokhman_hthestar@yahoo.co.id \\ Website: \\ https://jurnal.uinantasari.ac.id/index.php/adzka \\ Received: 29 Maret 2020; Accepted: 14 Mei 2020; Published: 1 Juni 2020
}

\begin{abstract}
This class action research aims to improve the critical thinking of students in learning Theme 7 Indahnya Keragaman di Negeriku using video critic learning strategy based on ATONG in class IV SD Negeri 3 Karangtengah. The study was conducted in three cycles. One cycle consists of one meeting. Stages of research using the Kevin and McTaggart's Model which consist of four stages, namely planning, implementation, observation, and reflection. Data collection tools used were evaluation tests, questionnaire sheets, interview guides, documents, teacher activity observation sheets, and student activity observation sheets. The validity of the data in this study uses the method triangulation. The results of the study using a video critic learning strategy based on ATONG showed an increase in students' critical thinking. Evaluation tests in the first cycle get an average value of 68 , the second cycle obtains an average value of 77 , and in the third cycle obtain an average value of. The number of students above the minimal completeness criteria that are as many as 24 students in cycles II and III has reached indicators of research success.
\end{abstract}

Key Words: critical thinking; video critic learning strategy; ATONG; elementary school

\begin{abstract}
ABSTRAK
Penelitian tindakan kelas ini bertujuan untuk meningkatkan berpikir kritis pada peserta didik dalam pembelajaran Tema 7 Indahnya Keragaman di Negeriku menggunakan strategi pembelajaran video critic berbasis ATONG pada kelas IV SD Negeri 3 Karangtengah. Penelitian dilaksanakan dalam tiga siklus. Satu siklus terdiri dari satu pertemuan. Tahapan penelitian menggunakan Model Kevin dan McTaggrt yang terdiri dari empat tahap, yaitu perencanaan, pelaksanaan, observasi dan refleksi. Alat pengumpulan data yang digunakan adalah tes evaluasi, lembar kuesioner, pedoman wawancara, dokumen, lembar observasi aktivitas guru, dan lembar observasi aktivitas peserta didik. Validitas data penelitian ini menggunakan triangulasi metode. Hasil penelitian menggunakan strategi pembelajaran video critic berbasis ATONG menunjukkan peningkatan berpikir kritis peserta didik. Tes evaluasi pada siklus I mendapatkan nilai rata-rata sebesar 68, siklus II, memperoleh nilai rata-rata sebesar 77, dan pada siklus III memperoleh nilai rata-rata sebesar. Jumlah peserta didik di atas KKM yaitu sebanyak 24 peserta didik pada siklus II dan III telah mencapai indikator keberhasilan penelitian.
\end{abstract}

Kata Kunci : berpikir kritis; strategi pembelajaran video critic; ATONG; sekolah dasar

\section{PENDAHULUAN}

Pendidikan merupakan suatu proses untuk mendapatkan keseimbangan perkembangan individu. Melalui pendidikan, individu dapat memperoleh wawasan baru yang mampu melengkapi wawasan yang diperoleh sebelumnya. Dalam prosesnya, individu diarahkan untuk berpikir dalam mengolah pengetahuan yang baru dan mampu menarik kesimpulan dari langkah- 
langkah yang telah dilaluinya. Oleh proses inilah, manusia dengan pengetahuan barunya dapat mengubah tingkah laku menjadi lebih baik.

Tujuan pendidikan yang dilaksanakan saat ini tidak semata untuk hari ini, tetapi juga untuk mengantisipasi apa yang akan terjadi di masa depan. Oleh karena itu, pendidikan harus selalu dikembangkan disesuaikan dengan tuntutan di masa depan. Pemerintah dalam mengembangkan pendidikan, saat ini telah menerapkan Kurikulum 2013. Menurut Kemendikbud (2014: 9) tujuan dirancangnya Kurikulum 2013 yaitu untuk menyiapkan anak Indonesia agar memiliki kompetensi sebagai diri dan warganegara yang beriman, kratif, inivatif, produktif, afektif dan memiliki kontribusi pada masyarakat, negara, bangsa dan peradaban dunia.

Implementasi pendidikan salah satunya melalui pembelajaran di dalam kelas. Pembelajaran akan mencapai hasil yang optimal apabila peserta didik berperan secara aktif dalam proses pembelajaran. Keterlibatan peserta didik secara aktif maka kemampuan peserta didik akan terlihat. Kemampuan yang harus dimiliki peserta didik saat ini yaitu berpikir kritis. Florea dan Hurjui (2014: 566) mengatakan bahwa kemampuan berpikir kritis merupakan suatu proses berpikir yang aktif dan kompleks dengan mengakumulasikan informasi untuk memecahkan permasalahan. Peserta didik dalam menganalisis, mengolah, menyimpulkan, menginterpretasikan materi pembelajaran dan pengambilan keputusan yang tepat harus diupayakan pada proses pembelajaran. Memiliki kemampuan berpikir kritis yang baik membuat peserta didik dalam menganalisis, mengolah, menyimpulkan, dan mengambil keputusan akan optimal.

Berdasarkan pada observasi proses pembelajaran di kelas IV SD Negeri 3 Karangtengah, ditemukan beberapa permasalahan di antaranya yaitu: (1) Peserta didik belum mampu menyimpulkan materi maupun menemukan konsep sendiri, berarti kemampuan menalar peserta didik masih rendah (2) Tidak ada peserta didik yang menyampaikan pendapat atau gagasan pada proses pembelajaran. Pembiasaan peserta didik dalam menyampaikan pendapat dapat melatih peserta didik untuk meluangkan pemikiran - pemikiran mengenai hal yang dihadapinya (3) Kurangnya pemahaman peserta didik dalam menanggapi pertanyaan guru salah satunya karena kemampuan analisis pertanyaan peserta didik masih rendah, sehingga jawaban dari peserta didik belum sesuai yang diinginkan. Ketiga permasalahan dalam proses pembelajaran tersebut memiliki indikasi bahwa kemampuan berpikir kritis peserta didik masih rendah. Wawancara yang dilakukan dengan guru kelas IV mendapatkan hasil bahwa peserta didik belum terbiasa dihadapkan dengan soal domain kognitif $\mathrm{C} 4 \mathrm{ke}$ atas dan masih dihadapkan dengan tipe soal domain kognitif C1-C3 karena peserta didik masih kesulitan untuk mengerjakan soal tipe domain kognitif $\mathrm{C} 4$ ke atas. Soal dengan domain kognitif C4 menurut Yusuf dan Widyaningsih (2018: 46) merupakan jenis soal yang memerlukan penalaran dan analisis.

Berpikir kritis peserta didik kelas IV SD Negeri 3 Karangtengah dapat dikatakan rendah karena belum munculnya aspek-aspek indikator berpikir kritis menurut Ennis (Susanto, 2013: 125), antara lain yaitu menyimpulkan, mengatur strategi dan taktik (menyampaikan pendapat), dan memberikan penjelasan sederhana (menganalisis pertanyaan). Refleksi terhadap permasalahan tersebut adalah perlu adanya inovasi pembelajaran aktif yang memiliki orientasi pada peserta didik sehingga mampu meningkatkan berpikir kritis pada peserta didik. Upaya dalam meningkatkan kemampuan berpikir kritis dapat menggunakan strategi, metode, model, maupun teknik pembelajaran yang sesuai dengan indikator berpikir kritis.

Berpikir kritis ini menjadi sangat penting karena pengambilan keputusan untuk memecahkan masalah perlu pemikiran yang mendalam. Johson (Hidayah, Salimi, \& Susiani, 2017: 129) mengatakan dengan memiliki berpikir kritis yang mumpuni, peserta didik dapat mempelajari permasalahan yang dihadapinya secara sistematis. Dengan adanya aktivitaspeserta 
didik melalui proses berpikir kritis, maka konsep akan lebih bertahan lama dan pembelajaran menjadi bermakna serta pemecahan masalah akan lebih mudah diatasi.

Inovasi pembelajaran berpikir kritis dapat dengan menerapkan strategi pembelajaran video critic berbasis ATONG (Amati, Tanya, Olah, Nalar, Gagas). Strategi pembelajaran video critic menurut Silberman (2017: 138) merupakan strategi yang menuntut peserta didik agar mampu menyampaikan pendapatnya dengan melakukan analisa terhadap tayangan video dan menyampaikan kritik yang terstruktur. Peserta didik dalam proses pembelajaran lebih terlibat langsung dan guru berperan sebagai fasilitator dengan menyiapkan langkah-langkah pembelajaran dan mempersiapkan video sebagai stimulan. Peran video sebagai media dapat menarik perhatian peserta didik sehingga pembelajaran menjadi menyenangkan. Arsyad (Ayu, Triwoelandari \& Fahri, 2019: 66) mengatakan peran video sebagai media dapat memperjelas informasi sehingga memperlancar dan meningkatkan proses pembelajaran, hasil belajar, maupun motivasi siswa dalam berinteraksi pada pembelajaran. Dengan rasa yang menyenangkan dan adanya motivasi membuat peserta didik akan lebih bersemangat dalam proses pembelajaran. Mulyanti (2016: 29) mengatakan bahwa video critic bertujuan untuk memberikan stimulan dan meningkatkan kreativitas peserta didik, serta mendorong peserta didik untuk menghayati permasalahan.

Pembelajaran dengan menerapkan strategi pembelajaran video critic dipadukan dengan ATONG, langkah-langkah pembelajaran dipolakan untuk amati, tanya, olah, nalar, gagas. Muslim, dkk (2015:44) mengatakan tahap atau pola amati yaitu aktivitas yang dilakukan peserta didik adalah mengamati media atau obyek yang digunakan dalam pembelajaran. Olah dan nalar pada pola ATONG memperkuat hasil temuan dari analisis informasi pada video dan pertanyaan yang diberikan guru sebelumnya pada tahap tanya. Dari hasil temuan informasi yang diperoleh, peserta didik diarahkan untuk memberikan kritikan dan gagasannya. Berkaitan dengan permasalahan yang dihadapi di kelas IV SD Negeri 3 Karangetengah, maka peneliti melaksanakan penelitian tindakan kelas dengan menerapkan strategi pembelajaran video critic berbasis ATONG untuk meningkatkan berpikir kritis peserta didik.

\section{METODE PENELITIAN}

Penelitian ini dilaksanakan di Kelas IV SD Negeri 3 Karangtengah dengan jumlah peserta didik sebanyak 31 orang. Jenis penelitian ini adalah Penelitian Tindakan Kelas (PTK). Penelitian ini merupakan penelitian kolaboratif yang melibatkan peneliti, observer, dan guru kelas. Tampubolon (2014: 18) berpendapat bahwa PTK adalah penelitian yang dilakukan secara praktik di dalam kelas dengan tujuan memperbaiki kualitas proses pembelajaran, hasil belajar, dan menemukan model pembelajaran inovatif untuk memecahkan permasalahan ditemukan di dalam kelas. Model PTK yang digunakan dalam penelitian adalah model PTK Kemmis dan McTaggart. Satu siklus PTK terdiri dari empat tahap yaitu perencanaan, pelaksanan/tindakan, observasi, dan refleksi. Taniredja (2010: 24) mengatakan model Kemmis dan McTaggart, pada tahap tindakan (pelaksanaan) dan observasi menjadi satu kesatuan sehingga saat tindakan bersamaan dengan observasi

Teknik pengumpulan data dalam penelitian ini yaitu teknik tes dan nontes. Alat pengumpulan data tes yaitu soal pada tes evaluasi berpikir kritis sedangkan alat pengumpulan data nontes yaitu kuesioner, wawancara, dokumen, dan observasi. Analisis data tes evaluasi berpikir kritis menggunakan rumus menurut Purwanto (2010:112).

$$
\begin{aligned}
& S=\frac{R}{N} \times 100 \\
& \text { Keterangan: } \\
& \mathrm{S}=\text { nilai yang diharapkan (dicari) } \\
& \mathrm{R}=\text { jumlah skor dari item soal yang dijawab benar } \\
& \mathrm{N}=\text { skor maksimum dari tes tersebut }
\end{aligned}
$$


Dari nilai tes evaluasi peserta didik dapat diketahui rata-rata nilai secara klasikal dengan rumus menurut Sudjana (2011: 109).

$$
\begin{aligned}
& \bar{X}=\frac{\Sigma X}{N} \\
& \text { Keterangan: } \\
& M=\text { rata-rata (mean) } \\
& \Sigma X=\text { jumlah seluruh skor } \\
& \mathrm{N}=\text { banyaknya subyek }
\end{aligned}
$$

Berdasarkan hasil tes evaluasi dapat diketahui nilai dari setiap aspek indikator berpikir kritis dengan mengembangkan rumus menurut Purwanto (2010:112).

$$
\begin{aligned}
& S=\frac{R}{N} \times 100 \\
& \text { Keterangan: } \\
& S=\text { nilai per indikator } \\
& R=\text { jumlah skor seluruh peserta didik } \\
& \mathrm{N}=\text { jumlah skor maksimal } \mathrm{x} \text { jumlah peserta didik }
\end{aligned}
$$

Analisis data kuesioner peserta sebagai validitas data berpikir kritis peserta didik dengan menjumlah seluruh skor setiap pernyataan. Kuesioner peserta didik terdapat 10 pernyataan dengan rincian 5 pernyataan positif dan 5 pernyataan negatif.

Kuesioner menggunakan skala Likert. Aktivitas guru dan peserta didik dianalisis secara kuanitatif dan dideskripsikan secara kualitatif. Rumus untuk menghitung aktivitas guru dan peserta didik menggunakan rumus menurut Djamarah (2010:264) sebagai berikut.

$$
\begin{aligned}
& P=\frac{F}{N} \times 100 \% \\
& \text { Keterangan: } \\
& \mathrm{P}=\text { Persentase yang dicari } \\
& \mathrm{F}=\text { Jumlah skor yang diperoleh } \\
& \mathrm{N}=\text { Jumlah skor maksimal }
\end{aligned}
$$

Penelitian ini berhasil apabila telah memenuhi indikator keberhasilan. Indikator keberhasilan dalam penelitian ini yaitu sebanyak $75 \%$ peserta didik dari keseluruhan telah mencapai KKM dalam tes evaluasi berpikir kritis sebesar 70 .

\section{HASIL PENELITIAN DAN PEMBAHASAN}

\section{A. Hasil Penelitian}

Hasil penelitian tindakan kelas ini menemukan bahwa adanya peningkatan berpikir kritis peserta didik dengan menggunakan strategi pembelajaran video critic berbasis ATONG pada proses pembelajran. Dibuktikan dengan hasil tes evaluasi berpikir kritis peserta didik yang dilaksanakan di akhir pembelajaran pada setiap siklusnya. Dalam mengukur berpikir kritis, peserta didik diberikan tes tertulis sebagai evaluasi pembelajaran yang telah dilaksanakan. Jumlah butirs soal yang diberikan sebanyak 5 butir dengan jenis soal uraian. Setiap butir soal berdasar pada aspek indikator berpikir kritis menurut Ennis. Indikator-indikator berpikir kritis menurut Ennis (Susanto, 2013: 125) adalah sebagai berikut.

Tabel 1. Indikator Berpikir Kritis Menurut Ennis

\begin{tabular}{|l|l|l|}
\hline No. & \multicolumn{1}{|c|}{ Aspek Indikator } & \multicolumn{1}{c|}{ Indikator } \\
\hline 1. & $\begin{array}{l}\text { Memberikan penjelasan } \\
\text { sederhana }\end{array}$ & $\begin{array}{l}\text { a. Memfokuskan pertanyaan } \\
\text { b. Menganalisis pertanyaan } \\
\text { c. Bertanya tentang suatu penjelasan atau } \\
\text { tantangan }\end{array}$ \\
\hline
\end{tabular}




\begin{tabular}{|c|c|c|}
\hline No. & Aspek Indikator & Indikator \\
\hline 2. & $\begin{array}{l}\text { Membangun keterampilan } \\
\text { dasar }\end{array}$ & $\begin{array}{l}\text { a. Mempertimbangkan apakah sumber dapat } \\
\text { dipercaya } \\
\text { b. Mengamati dan mempertimbangkan suatu } \\
\text { laporan hasil observasi }\end{array}$ \\
\hline 3. & Menyimpulkan & $\begin{array}{l}\text { a. Mendeduksi dan mempertimbangkan hasil } \\
\text { deduksi } \\
\text { b. Menginduksi dan mempertimbangkan hasil } \\
\text { induksi } \\
\text { c. Membuat dan menentukan nilai } \\
\text { pertimbangan }\end{array}$ \\
\hline 4. & Memberikan penjelasan lanjut & $\begin{array}{l}\text { a. Mendefinisikan istilah dan pertimbangan } \\
\text { definisi dalam tiga dimensi } \\
\text { b. Mengidentifikasi asumsi }\end{array}$ \\
\hline 5. & Mengatur strategi dan taktik & $\begin{array}{l}\text { a. Menentukan tindakan } \\
\text { b. Berinteraksi dengan orang lain }\end{array}$ \\
\hline
\end{tabular}

Setiap butir soal merujuk pada satu aspek indikator berpikir kritis seperti Tabel 1. Dari 3 tes evaluasi berpikir kritis peserta didik terdapat peningkatan rata-rata hasil tes evaluasi berpikir kritis peserta didik. Peningkatan hasil tes evaluasi dapat dilihat pada Gambar 1sebagai berikut.

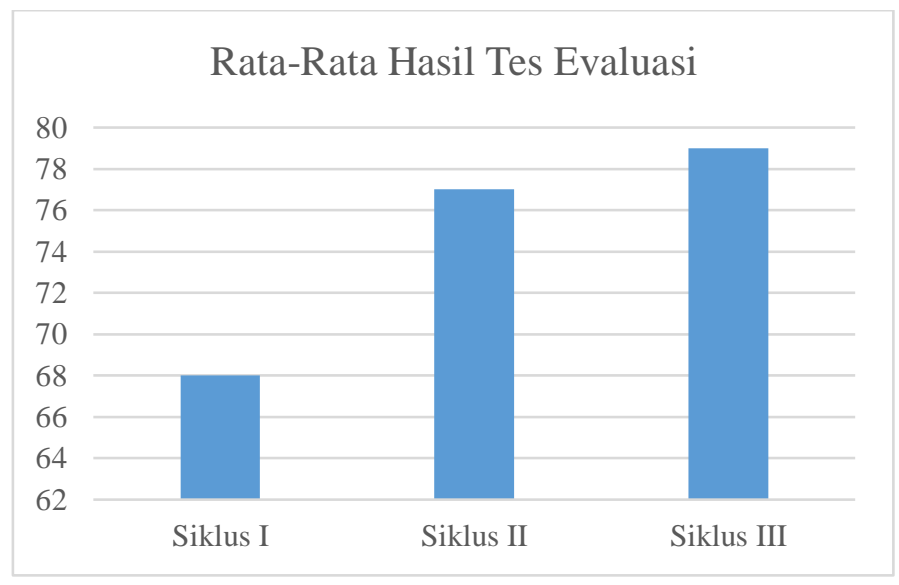

\section{Gambar 1. Rata-Rata Hasil Tes Evaluasi Berpikir Kritis Peserta Didik}

Gambar 1 tersebut menunjukkan bahwa nilai rata-rata hasil tes evaluasi peserta didik menunjukkan peningkatan dari siklus I sampai siklus III. Indikator keberhasilan penelitian yaitu 75\% peserta didik memperoleh nilai tes evaluasi di atas atau sama dengan 70. Pada siklus I, sebanyak 19 peserta didik yang mendapatkan nilai di atas KKM dengan rata-rata keseluruhan yaitu 68. Siklus II mendapatkan sebanyak 24 peserta didik dengan nilai di atas KKM dengan nilai ratarata sebesar 77, dan pada siklus III sebanyak 24 peserta didik mendapatkan nilai di atas KKM dengan nilai rata-rata sebesar 79. Berdasarkan indikator keberhasilan penelitian, siklus I belum mencapai indikator keberhasilan, namun pada siklus II dan siklus III sudah mencapai indikator keberhasilan.

Dari skor yang diperoleh peserta didik setiap butir soal pada tes evaluasi berpikir kritis dapat diketahui nilai keseluruhan per butir soal yang berdasarkan aspek indikator berpikir kritis. Adapun uraian nilai per butir soal yang berdasarkan aspek indikator berpikir kritis adalah sebagai berikut. 
Tabel 2. Nilai Per Butir Soal dari Tes Evaluasi Berpikir Kritis Peserta Didik

\begin{tabular}{|l|l|c|c|c|}
\hline No. & \multicolumn{1}{|c|}{ Aspek Indikator } & Siklus I & Siklus II & Siklus III \\
\hline 1. & Memberikan penjelasan sederhana & 67 & 89 & 80 \\
\hline 2. & Membangun keterampilan dasar & 81 & 71 & 77 \\
\hline 3. & Menyimpulkan & 40 & 72 & 70 \\
\hline 4. & Memberikan penjelasan lanjut & 71 & 70 & 77 \\
\hline 5. & Mengatur strategi dan taktik & 70 & 72 & 80 \\
\hline
\end{tabular}

Tabel 2 tersebut menunjukkan bahwa nilai per butir soal yang diperoleh dari tes evaluasi berpikir kritis mengalami adanya peningkatan dan penurunan. Aspek indikator berpikir kritis 1 dari siklus I ke siklus II mengalami peningkatan sebesar 22 tetapi menurun sebesar 9. Pada aspek indikator berpikir kritis 2 dari siklus I ke siklus II mengalami penurunan sebesar 10 dan meningkat pada siklus III sebesar 7. Pada aspek indikator berpikir kritis 3 mengalami peningkatan sebesar 32 dari siklus I ke siklus II dan turun sebesar 2 pada siklus III. Pada aspek indikator berpikir kritis 4 dari siklus I ke siklus II turun 1 dan meningkat sebesar 7 pada siklus III, dan pada aspek indikator berpikir kritis 5 mengalami peningkatan sebesar 2 ke siklus II dan meningkat kembali sebesar 8 pada siklus III.

Data hasil tes evaluasi berpikir kritis peserta didik menunjukkan peningkatan berpikir kritis peserta didik dan kemudian peneliti melakukan validitas data dengan memberikan kuesioner peserta didik dengan 10 butir pernyataan dengan rincian 5 butir pernyataan positif dan 5 butir pernyataan negatif. Setiap butir pernyataan pada kuesioner disesuaikan dengan materi pembelajaran setiap siklusnya dan mewakili aspek indikator berpikir kritis. Wawancara peserta didik dilakukan dengan mengambil sampel peserta didik yang mendapatkan hasil tes evaluasi dan kuesioner sangat baik dan kurang baik.

Peran guru dalam menyajikan pembelajaran sangat vital karena berhubungan dengan bagaimana hasil keluaran peserta didik dari proses belajar. Oleh karena itu, guru memiliki peran penting dalam peningkatan berpikir kritis peserta didik, yang senada dengan teori yang dikatakan Meredith dan Steelová (Valentová dan Brečka, 2019: 999). Peningkatan berpikir kritis yang dialami peserta didik dipengaruhi juga oleh guru dalam menyajikan pembelajaran menggunakan strategi pembelajaran video critic berbasis ATONG yang meningkat dari siklus I ke siklus III.. Adapun hasil observasi aktivitas guru siklus I, siklus II, dan siklus III adalah sebagai berikut.

Tabel 3. Hasil Observasi Aktivitas Guru Siklus I, Siklus II, Dan Siklus III

\begin{tabular}{|c|c|c|c|c|}
\hline No. & Siklus & Skor & Persentase & Kriteria \\
\hline 1. & I & 18 & $85 \%$ & Sangat Baik \\
\hline 2. & II & 20 & $100 \%$ & Sangat Baik \\
\hline 3. & III & 20 & $100 \%$ & Sangat Baik \\
\hline
\end{tabular}

Grafik hasil observasi aktivitas guru siklus I, siklus II, dan siklus III adalah sebagai berikut.

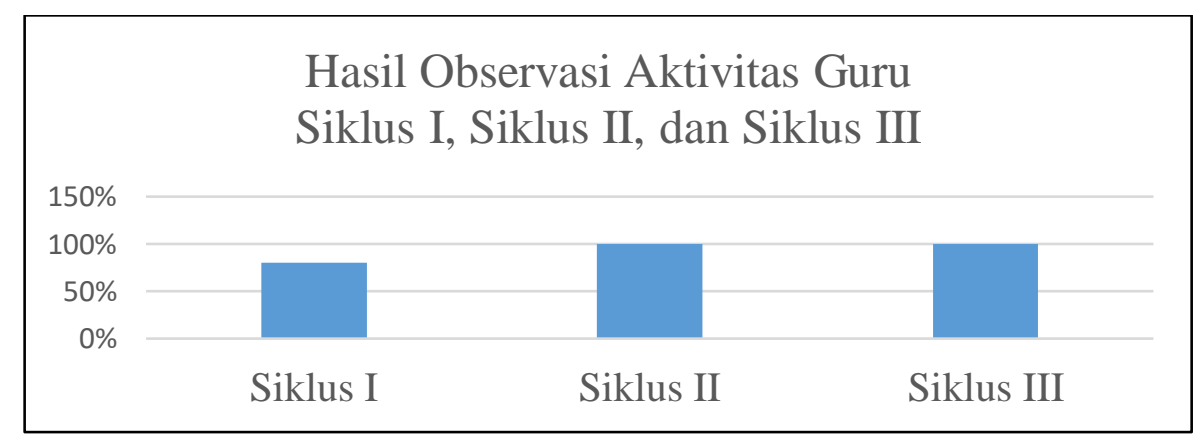




\section{Gambar 2. Diagram Batang Hasil Observasi Aktivitas Guru Siklus I, Siklus II, dan Siklus III}

Berdasarkan tabel 3 dan gambar 2 tersebut aktivitas guru berdasarkan aspek yang dilihat pada lembar observasi aktivitas guru mengalami peningkatan. Pada siklus I, sudah mencapai $85 \%$ atau sudah mencapai skor 18 dari 20 dan sudah memenuhi kriteria sangat baik. Pada siklus II menunjukkan kenaikan dengan mencapai $100 \%$ atau sudah mencapai skor 20 poin dari 20 dan sudah mencapai kriteria sangat baik. Siklus III mengalami hasil yang stagnan dari siklus yang juga mencapai $100 \%$.

\section{B. Pembahasan}

Penggunaan strategi pembelajaran video critic berbasis ATONG memiliki pengaruh yang baik pada proses dan hasil pembelajaran. Dibuktikan berpikir kritis peserta didik meningkat dan mampu menyelesaikan permasalahan dalam proses pembelajaran dan tes evaluasi yang menggunakan soal HOTS (High Order Thingking Skill). Hasil tes evaluasi berpikir kritis tersebut ditriangulasikan dengan kuesioner dan wawancara peserta didik.

Pembelajaran dengan menggunakan strategi pembelajaran video critic mendorong peserta didik untuk mampu menilai dan mengkritisi video yang telah diamati sebelumnya. Peserta didik tidak lagi menjadi subyek belajar yang konvensional, tetapi berubah menjadi subyek belajar yang aktif. Mulyanti (2016:30) menjelaskan bahwa manfaat strategi pembelajaran video critic di antaranya yaitu membuat otak menjadi aktif, peserta tidak mudah melupakan materi pelajaran, proses pembelajaran menjadi menyenangkan, otak dalam memproses pembelajaran lebih baik. Strategi pembelajaran video critic dengan pola pembelajaran ATONG (Amati, Tanya, Olah, Nalar, dan Gagas) memosisikan peserta didik sebagai kritikus video dengan langkah-langkah pembelajaran yang dipolakan mengamati, menanya, mengolah, menalar, dan menggagas.

Kegiatan mengamati dalam pembelajaran menjadi kunci dalam mendapatkan informasi. Senada dengan penjelasan berpikir kritis menurut Susanto (2013: 123) yang mengatakan bahwa individu yang memiliki berpikir kritis akan mencermati dan menganalisis. Kegiatan peserta didik dalam mengamati video juga di dalamnya juga dituntut untuk mencermati isi materi di dalam video. Dengan mengamati dengan baik tentunya bisa menyelesaikan soal yang diberikan.

Pola pembelajaran kedua dari ATONG setelah amati yaitu tanya. Dalam proses pembelajaran, kegiatan tanya ini dari guru ke peserta didik melalui LKPD yang diberikan setelah peserta didik mengamati video. Soal-soal dalam LKPD seputar materi yang disampaikan dalam video, dan salah satu soal dari LKPD yaitu perintah dalam LKPD yaitu membuat kritikan video yang telah diamati sebelumnya.

Dalam menumbuhkan berpikir kritis peserta didik, tantangan atau permasalahan yang dihadapi peserta didik dalam hal ini adalah LKPD perlu peserta didik kaji terlebih dahulu dan nalar sehingga peserta didik dapat menyelesaikan LKPD dengan baik. Oleh karena itu, pola berikutnya yaitu olah dan nalar. Peserta didik diberikan kesempatan oleh guru untuk memahami LKPD yang telah diterima. Saat tahap peserta didik memahami LKPD inilah pola olah berlangsung yang selanjutnya peserta didik menonton video kembali untuk mengaitkan soal dari LKPD dengan materi dalam video. Mengaitkan soal yang telah dipahami dengan materi dalam video ini adalah tahap nalar. Peserta didik dikondisikan untuk mampu menyampaikan hasil diskusi atas LKPD dan menyampaikan kritikan video ini merupakan perwujudan dari gagas dalam ATONG. Pembentukan peserta didik untuk menyampaikan hasil diskusi atau pendapatnya membuat peserta didik diusahakan untuk berani menuangkan hasil pemikirannya.

Guru memiliki peran sentral dalam mengembangkan berpikir kritis peserta didiknya. Tilaar, dkk (2011: 17) mengatakan bahwa dengan guru mengembangkan berpikir kritis berati 
memberikan penghargaan kepada peserta didik. Berpikir kritis adalah suatu kemampuan berpikir yang perlu dimiliki peserta didik. Menurut Hidayah, dkk (2017: 129) mengatakan bahwa kemampuan seseorang dalam berpikir akan berpengaruh pada keberhasilan seseorang karena berkaitan dengan apa yang akan dikerjakan atau dilakukan. Dengan memiliki berpikir kritis yang baik maka peserta didik mampu menimbang untuk menentukan langkah yang akan dipilih.

\section{PENUTUP}

Berdasarkan hasil penelitian tindakan kelas yang dilakukan selama tiga siklus dalam peningkatan berpikir kritis menggunakan strategi pembelajaran video critic berbasis ATONG, dapat diperoleh simpulan bahwa pembelajaran menggunakan strategi pembelajaran video critic berbasis ATONG dapat meningkatkan berpikir kritis peserta. Pada siklus I mendapatkan 19 peserta didik di atas KKM. Hasil yang diperoleh pada siklus I ini belum memenuhi indikator keberhasilan secara klasikal dengan $75 \%$ peserta didik di atas KKM dengan nilai rata-rata sebesar 68. Hasil siklus II mengalami peningkatan dan mendapatkan peserta didik di atas KKM sebanyak 24 peserta didik. Hasil tersebut memenuhi 75\% peserta didik di atas KKM dengan nilai rata-rata sebesar 77 dan menunjukkan indikator keberhasilan penelitian. Siklus III didapatkan 24 peserta didik di atas KKM. Namun nilai rata-rata meningkat menjadi sebesar 79. Hasil siklus III sudah memenuhi indikator keberhasilan penelitian.

Adapun saran bagi lembaga pendidikan ataupun guru yaitu dapat menerapkan pembelajaran menggunakan strategi pembelajaran video critic berbasis ATONG sebagai bahan pertimbangan memperbaiki proses pembelajaran untuk meningkatkan berpikir kritis peserta didik. Strategi pembelajaran video critic berbasis ATONG harus dilaksanakan sesuai dengan langkah-langkahnya, sehingga guru harus menguasai dan memahami langkah-langkah pembelajaran strategi pembelajaran video critic berbasis ATONG dengan tepat dan benar agar sesuai dengan tujuan yang diharapkan.

\section{DAFTAR PUSTAKA}

Ali, M. \& Asrori, M. (2014). Metodologi dan Aplikasi Riset Pendidikan. Bumi Aksara: Jakarta Ayu, D.W., Triwoelandari, R., \& Fahri, M. (2019). Media Pembelajaran Powtoon Terintegrasi Nilai-Nilai Agama pada Pembelajaran IPA untuk Mengembangkan Karakter. Al-Adzka: Jurnal Ilmiah Pendidikan Guru Madrasah Ibtidaiyah. 9(2): 65-74

Djamarah, S. B. (2005). Guru dan Anak Didik dalam Interaksi Edukatif: Suatu Pendekatan Teoritis Psikologis. Rineka Cipta: Jakarta

Florea, N. M. \& Hurjui, E. (2015). Critical Thinking in Elementary School Children. Procedia - Social and Behavioral Sciences. 180: 565-572

Hidayah, R., Salimi, M., \& Susiani, T.S. (2017). Critical Thinking Skill: Konsep dan Indikator Penilaian. Jurnal Taman Cendekia. 1(2): 127-133

Kementerian Pendidikan dan Kebudayaan. (2014). Materi Pelatihan Implementasi Kurikulum 2013 Tahun 2014. Kemdikbud: Jakarta

Mulyanti, P. F. (2016). Penerapan Metode Video Critics untuk Meningkatkan Pemahaman Informasi Bahaya Merokok. Insight: Jurnal Bimbingan Konseling. (52): 28-49

Muslim, A. H., Supartono \& Rusilowati, A. (2015). Pengembangan Perangkat Pembelajaran IPS Model Cooperative Tipe TGT Berbasis ATONG Bagi Siswa Sekolah Dasar. Dinamika Jurnal Pendidikan Dasar. 7(1): 42-51

Purwanto, N. M. (2010). Prinsip-Prinsip dan Teknik Evaluasi Pengajaran. Remaja Rosdakarya: Bandung

Silberman, M. L. (1996). Active Learning: 101 Strategies to Teach Any Subject. Allyn dan Bacon: Boston. Terjemahan Muttaqien, R. (2017). Active Learning: 101 Cara Belajar Siswa Aktif. Nuansa Cendekia: Bandung

Sudjana, N. (2011). Penilaian Hasil Proses Belajar Mengajar. Remaja Rosdakarya: Bandung 
Susanto, A. (2013). Teori Belajar \& Pembelajaran di Sekolah Dasar. Prenadamedia Group: Jakarta

Tampubolon, S. M. (2014). Penelitian Tindakan Kelas untuk Pengembangan Profesi Pendidik dan Keilmuan. Erlangga: Jakarta

Taniredja, T., Pujiati, I., \& Nyata. (2010). Penelitian Tindakan Kelas untuk Pengembangan Profesi Guru Pratik, Praktis, dan Mudah. Alfabeta: Bandung

Tilaar, H. A. R., Paat, J. P., \& Paat, L. (2011). Pedagogik Kritis: Perkembangan, Substansi dan Perkembangannya di Indonesia. Rineka Cipta: Jakarta

Valentová, M. \& Brečka, P. (2009). Implementation of the Critical Thinking Strategies in the School Subject Technology: A Preliminary Study. TEM Journal. 8(3): 998-1004 
Habib Nurokhman, dkk 